\title{
More French researchers getting their first job only after 30
}

\section{Paris}

AN unpublished statistical survey of recruitment within France's largest state research employer, the Centre National de la Recherche Scientifique (CNRS), shows that the new crop of young scientists are not so young. The mean age of researchers at the lowest entry grade is now 30 years. An informal organization representing candidates for admission to CNRS, calling itself the Collectif des Admissibles, sees in these figures evidence of the government campaign to persuade young scientists to look outside the public sector for employment (see Nature 329, 380 ; 1987). But within the CNRS administration, the interpretation is more prosaic; the figures simply reflect a general tendency to stay longer within tertiary education before seeking employment.

Since 1984, CNRS researchers have had civil service status, giving them jobs for life once accepted into the system. In 1986 , with the arrival of a new, right-wing government, the former Research Minister, Alain Devaquet, took steps to stem the growth in state research appointments enjoyed under the socialists and commissioned an inquiry to look for ways to restructure the CNRS. Although this inquiry is still incomplete, there has been a one-third reduction in the number of posts available for 1987 , while both the new Minister, Jacques Valade, and the CNRS director, Serge Feneuille, are known to favour replacing initial lifetime contracts by a 'trial period' of short-term postdoctoral posts, in line with other European and US procedures. In Britain and the United States, however, postgraduates finish their doctorates three or four years earlier than their French colleagues.

Increased competition for jobs has raised the threshold for admission, and hence the age of candidates. The introduction, in 1985 , of a 'three-year rule' giving initially unsuccessful candidates only two more tries will raise the average age of entry even further, as even good candidates are unlikely to get in the first time. Ironically, the aim of the three-year rule, introduced when over 600 posts were available annually (compared to 398 in 1986 and 150 for 1988), was to inject young blood into the CNRS.

However, the CNRS claims the ruling cannot be blamed for the increase in age of recruits as its effects will be visible for the first time this year, while the average age of successful candidates in most disciplines has increased steadily since 1983.

Some young scientists nevertheless view the statistics with concern. Eric Bringuier, secretary of the Collectif des Admissibles (which won its legal action contesting the annulment of 250 appointments in 1986 by Devaquet - see Nature 327, 746; 1987), says the narrow chance of joining CNRS on the first attempt means candidates have to take up "precarious and sometimes unpaid" work while waiting. Overall, 35 per cent of candidates for the lowest two grades of post received grants before being admitted, 10 per cent were unemployed and 3 per cent were doing casual work.

The Collectif des Admissibles should have dissolved when its members won their fight for reinstatement last year, but, explained Hervé Chneiweiss, a biologist at the Collège de France, they are still not satisfied. A CNRS statute requires researchers to stay at their laboratory for the first 18 months after taking up their appointment - ruling out travel to foreign laboratories or conferences. The Collectif wants retrospective application of this rule to take account of their 12-month wait for reinstatement.

The CNRS survey shows that ageing of 'new blood' in public-sector research is more apparent for some disciplines than others. In human sciences, where 152 applications were received in 1986 for 15 posts, the mean age of new appointments at the lowest grade is now 36 years. In contrast, so few candidates now apply for jobs in nuclear and particle physics that means have little statistical value. At the Institut National de la Santé et de la Recherche Médicale (INSERM), a more determined 'new blood' policy has so far offset the ageing seen at CNRS.

The number of candidates to apply for admission in the current rounds is down on previous years. The cuts in the number of posts available, the turmoil of last year and what is seen as an 'unfavourable' government attitude to research have, says Bringuier, frightened off potential applicants. CNRS officials say the fall in applications was "only" about 200. Meanwhile, the timetable for 1988 admissions is still upset by the 1986 setback, meaning an extra six months of financial insecurity for candidates

Peter Coles

- Following a government-level decision, the French direct-broadcast television satellite TDF-1, due to be put into geostationary orbit by an Ariane rocket in June this year, will now be launched in the autumn. The change of plans is thought to be related to operating difficulties with the satellite's German twin, TV-SAT, launched last year. One of TV-SAT's two solar panels has remained folded despite several attempts to release it. In a diplomatic gesture by Prime Minister Jacques Chirac, TDF-1's place on flight V-24 has been offered to India for its INSAT-1C telecommunications satellite.

\section{Rich rewards for medical prize-winners}

\section{London}

THE $\mathfrak{0 . 7 5}$ million 1988 Louis Jeantet Award for Medicine, candidates for which have to be working in Western Europe, has been split three ways. The newly appointed head of the National Institute for Medical Research on the outskirts of London, John Skehel, is cited for his research on the haemagglutinin protein of influenza virus. His share of the award will be spent on developing antiviral agents that block the interaction of this protein with its cellsurface receptor. Rolf Zinkernagel, of the University of Zurich, who shared in the discovery of 'MHC restriction', is planning to use his prize money to continue investigating how the immune system deals with viruses, the area of research for which he is cited.

The third winner, Bert Sakmann of the Max Planck Institute for Biophysical Chemistry in Göttingen, receives his award for his studies of the ionic basis of neural excitation. These have been based, in large part, on the technique of patch clamping that he developed with Erwin Neher. He will use his award to bring the techniques of molecular biology to bear on the subject, an approach he has been pursuing with the help of Japanese collaborators.

In addition to research funds the three winners each receive a personal prize of about $£ 30,000$. The prizes will be awarded in Geneva in April. Peter Newmark
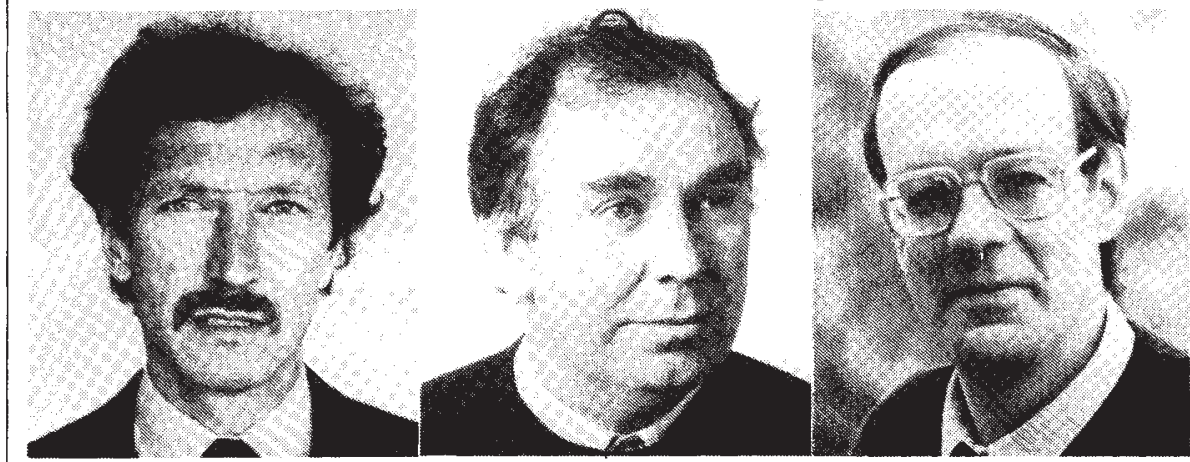

The winning Jeantet trio: Rolf Zinkernagel, John Skehel and Bert Sakmann 